\title{
Journal of Comprehensive Pharmacy
}

$\underline{\text { Research Article }}$

Available Online at: $\underline{w w w . j c p o n l i n e . i n}$

ISSN NO: 2349-5669

\section{Formulation design and in vitro Evaluation of Floating tablets of an Antiulcer drug using Different Synthetic and Natural polymer}

\author{
Sarath Chandiran Irisappan ${ }^{\text {a }}$, Nagarjuna Paleti ${ }^{b^{*}}$, PavanKumar Balagani ${ }^{\text {b }}$, Kavitha Pallepati ${ }^{\text {b }}$ \\ ${ }^{a}$ Professor, Department of Pharmaceutics, Gokula Krishna College of Pharmacy, Sullurpet-524121, A.P, India. \\ $b^{*}$ Department of Pharmaceutics, Gokula Krishna College of Pharmacy, Sullurpet-524121, A.P, India.
}

\begin{abstract}
ARTICLE INFO
Article history:

Received 21 April 2016

Accepted 26 May 2016

Available online 27 June 2016
\end{abstract}

*Corresponding author:

Nagarjuna Paleti

Email:

Nagpharma147@gmail.com

Tel.:+91-9393934012.

\section{ABSTRACT}

Famotidine is a histamine $\mathrm{H}_{2}$-receptor antagonist and it is widely prescribed in gastric and duodenal ulcers, Zollinger- Ellison syndrome and gastroesophageal reflux disease (GERD) but susceptible to metabolism by colonic bacteria, which in turn has ramifications for drug delivery and absorption. Thus, it is logically way to improve the therapeutic efficacy of the drug if the gastric residence time of the dosage form is increased at the absorption site. Moreover, the drug is highly soluble in aqueous environment, it is necessary to reduce/controls the drug release from the formulations. Therefore, the main aim of this research was to formulate controlled-release floating tablets of Famotidine in an effort to prolong its residence time in the stomach. The drug and polymer compatibility was studied by subjecting physical mixtures of drug and polymers to FTIR spectroscopy. Five batches of tablets were prepared by using HPMC K $100 \mathrm{M}$ and Hibiscus mucilage in different concentrations along with gas generating agent sodium bicarbonate. The Tablets were prepared by direct compression technique. The natural polymer was isolated and extracted from leaves of Hibiscus rosa-sinensis in our laboratory and that is used as a polymer in combination with HPMC K $100 \mathrm{M}$ to prepare floating tablets. The prepared floating tablets were evaluated for weight variation, hardness, thickness, friability, drug content uniformity, buoyancy lag time, total floating time and in vitro dissolution studies. Results were found that hardness $4-5 \mathrm{~kg} / \mathrm{cm}^{2}$ and friability test was found to less than $1 \%$ in all the cases. Drug content ranging from 96.13 to $99.67 \%$ and the \% drug release was in the order of F1> F2> F3> F4> F5. It reveals that increase the Hibiscus mucilage concentration decrease the release of Famotidine from floating tablets and it was showed that the Hibiscus mucilage exhibit excellent retarding effect on drug release from the floating tablets. Among the formulations studied, formulation F3 showed optimum release characteristics. The release mechanisms and the drug release rate kinetics of the tablets were examined using in vitro dissolution testing model. The drug release from all the formulations followed Peppas model and the ' $n$ ' value of F2, F3 and F4 was found to be between $0.5-1.0$ indicates anomalous/non-fickian type (diffusion and erosion) of release mechanism except formulation F5 followed Zero order kinetics and showed super case II transport mechanism (i.e., $n=1.449$ ). The ' $n$ ' value of $F 1$ was found to be 0.36 indicates fickian type of release mechanism. Stability study was carried out for optimized formulation F3 at $40^{\circ} \mathrm{C} / 75 \% \mathrm{RH}$ for 30 days. The results of stability studies revealed no significant change in physical appearance; hardness and drug content indicating the formulation was stable.

Key words: Famotidine, Gastric retention, Hibiscus mucilage, Controlled release. 


\section{INTRODUCTION}

Oral route is the most convenient and extensively utilized route for drug administration among all the routes that have been employed for systemic delivery of drugs via various pharmaceutical products of different dosage forms. Oral route of administration has been received more attention in the pharmaceutical field because of its ease of administration, patient compliance, least sterility constraints and flexible design of dosage forms [1]. Effective oral drug delivery may depend upon the factors such as gastric emptying process, gastrointestinal transit time of dosage form, drug release from the dosage form and site of absorption of drugs. Most of the oral dosage forms possess several physiological limitations such as variable gastrointestinal transit, because of variable gastric emptying leading to non-uniform absorption profiles, incomplete drug release and shorter residence time of the dosage form in the stomach. This leads to incomplete absorption of drugs having absorption window especially in the upper part of the small intestine, as once the drug passes down the absorption site, the remaining quantity goes unabsorbed [2]. Conventional drug delivery systems achieve as well as maintain the drug concentration within the therapeutically effective range needed for treatment only when taken several times a day [3]. This results significant fluctuations in drug levels and also the drugs that are easily absorbed from gastro intestinal tract and have short half life are eliminated quickly from systemic circulation. These drugs require frequent dosing to achieve therapeutic activity. To avoid these limitations attempts have been made to develop many novel drug delivery systems that could revolutionize method of medication and provide a number of therapeutic benefits.

Floating drug delivery systems [4-11] or hydro dynamically balanced systems have bulk density lower than gastric fluids $\left(1.004 \mathrm{~g} / \mathrm{cm}^{3)}\right.$ and therefore remain floating in the stomach without affecting the gastric emptying rate for a prolonged period. The drug is slowly released at a desired rate from the floating system and after the complete release; the residual system is expelled from the stomach. This leads to an increase in the GRT, which could be advantageous because it reduces the inter subject variability in absorption and lower probability of dose dumping by reducing frequency of dosing, and it also advantageous for local action of drugs in the stomach. Moreover, it improves the absorption of drugs with short-half life, reduces drug waste, and improves solubility of drugs that are less soluble in high $\mathrm{pH}$ environment.

Famotidine is a competitive \& reversible inhibitor of $\mathrm{H}_{2}$ receptor antagonist which inhibits the direct action of histamine on gastric acid secretion. It also reduces basal acid secretion, nocturnal acid secretion and food stimulated acid secretion. The drug is susceptible to metabolism by colonic bacteria, which in turn has ramifications for drug delivery and absorption. Moreover, the drug is highly soluble in aqueous environment it is necessary to reduce/controls the drug release from the formulations.

Therefore, in this research study it was aimed to formulate controlled release floating tablets of Famotidine using HPMC K 100M and Hibiscus polysaccharide in different concentrations to prolong GRT of the drug in stomach, which may Increase the effectiveness in therapy, reduce dosing frequency, improving patient compliance and to maintain plasma concentration of drug in therapeutic range for longer time.

\section{MATERIALS AND METHODS}

Famotidine, was obtained as gift sample from Shasun pharmaceuticals Ltd, Pondicherry HPMC K1OOM were purchased from Taian Ruitai cellulose co., Ltd, P.R. China, Hibiscus mucilage, Microcrystalline cellulose were purchased from Mingtai chemical co., Ltd, Taiwan, Sodium bicarbonate were purchase from Central drug house Pvt. Ltd, New Delhi, Citric acid from Spectrum chemicals, Cochin Magnesium stearate, Talc from S.D. Fine - Chem. Ltd, Mumbai. The chemical reagents used were of analytical grade.

\section{Drug - Excipient compatibility study [12]:}

\section{Drug - Excipient compatibility study by Thin Layer Chromatography}

In this method drug and excipients in 1:2 ratio were mixed and analyzed for compatibility by using TLC after one, two, three and four weeks. $10 \mu$ l of reference and test solutions were applied as spots on the dry activated plate. The solvent system was allowed to run up to desired height; the plates were removed and allowed to dry. The dry plates were then exposed to iodine vapors in a chamber to observe the spots. The plates were then removed and the $\mathrm{R}_{f}$ values calculated.

\section{Drug - Excipient compatibility study by determination of $\lambda_{\max }$ :}

A solution of Famotidine containing $10 \mu \mathrm{g} / \mathrm{ml}$ was prepared in $0.1 \mathrm{~N} \mathrm{HCl}$ and scanned in the range of 200 - $400 \mathrm{~nm}$ using UV-Visible spectrophotometer. The same method is followed to Drug-Excipient mixture for determining $\lambda_{\max }$.

\section{Drug - Excipient compatibility study by Fourier Transform Infrared Radiation (FTIR)}

FTIR spectroscopy was carried out to check the compatibility between the drug and excipients, where spectral measurements of drug alone and with 
polymers were taken at ambient temperature and analyzed for major interaction. Samples and $\mathrm{KBr}$ were taken in 1:100 ratio in a mortar and triturated. A small amount of triturate was taken into a pellet maker and was compressed at $10 \mathrm{~kg} / \mathrm{cm}^{2}$ to form a transparent pellet using a hydraulic press. The pellet was kept in the sample holder and scanned between 4000 - 400 $\mathrm{cm}^{-1}$ using FTIR spectrometer (Sipra lab Ltd). This was done qualitatively in order to assess the pattern of peaks and for comparison purpose.

\section{Preparation of standard calibration curve of Famotidine}

Famotidine showed one strong absorption peak at 242 $\mathrm{nm}$ in $0.1 \mathrm{~N} \mathrm{HCl}$, which represents the maximum absorbance $\left(\lambda_{\max }\right)$ of the drug.

\section{Procedure}

\section{Preparation of standard solution:}

Primary stock solution: $100 \mathrm{mg}$ of Famotidine was weighed accurately into $100 \mathrm{ml}$ volumetric flask and dissolved in small quantity of $0.1 \mathrm{~N} \mathrm{HCl}$, the volume was made up with the $0.1 \mathrm{~N} \mathrm{HCl}$

Secondary stock solution: Pipette $10 \mathrm{ml}$ of the solution into another $100 \mathrm{ml}$ volumetric flask and the volume was made with the $0.1 \mathrm{~N} \mathrm{HCl}$ (i.e.: $100 \mu \mathrm{g} / \mathrm{ml}$ in $0.1 \mathrm{~N} \mathrm{HCl}$ )

Preparation of working standard solution: Aliquots of standard solution $1 \mathrm{ml}, 2 \mathrm{ml}, 3 \mathrm{ml}, 4 \mathrm{ml}, 5 \mathrm{ml}$ were pipette into $10 \mathrm{ml}$ volumetric flasks. The volume made up with $0.1 \mathrm{~N} \mathrm{HCl}$. The absorbance of each concentration was measured at $242 \mathrm{~nm}$ using Systronics 117 UV-Visible spectrophotometer against $0.1 \mathrm{~N} \mathrm{HCl}$ as a blank.

The absorbance data for standard calibration curve is given in Table 6. The standard calibration curve yields a straight line, which shows that the drug follows Beer's range in the concentration range of $10-50$ $\mu \mathrm{g} / \mathrm{ml}$. The standard calibration curve of Famotidine is shown in Fig 1.

\section{Formulation of floating tablets [13]}

Floating tablets containing Famotidine were prepared by direct compression technique using varying concentrations of HPMC K 100M and Hibiscus mucilage with sodium bicarbonate. All the ingredients except magnesium stearate were blended in glass mortar uniformly. After sufficient mixing the powder blend was lubricated with magnesium stearate and purified talc. The tablets were compressed by using Rimek mini press 1 tablet punching machine with flat face punches \& die (12mm in diameter). The compositions of tablets were shown in Table 1.

\section{Evaluation of floating tablets}

\section{Precompression parameters}

\section{Bulk density [14]:}

Density is defined as weight per unit volume. Bulk density, $\rho_{b}$, is defined as the mass of the powder divided by the bulk volume and is expressed as $\mathrm{gm} / \mathrm{cm}^{3}$. The bulk density of a powder primarily depends on particle size distribution, particle shape and the tendency of particles to adhere together.

Bulk density is very important in the size of containers needed for handling, shipping, and storage of raw material and blend. It is also important in size blending equipment.15 g powder blend introduced into a dry $100 \mathrm{ml}$ cylinder, without compacting. The powder was carefully leveled without compacting and the unsettled apparent volume was read. The bulk density was calculated using the following formula.

$$
\text { bulk density }=\frac{\text { Weight of sample }}{\text { Apparent v olume of powder }}
$$

\section{Tapped density [14]:}

After carrying out the procedure as given in the measurement of bulk density the cylinder containing the sample was tapped 500 times initially followed by an additional taps of 750 times until difference between succeeding measurement is less than $2 \%$ and then tapped volume, tapped density was measured, to the nearest graduated unit. The tapped density was calculated, in gm per $\mathrm{ml}$, using the following formula.

$$
\text { tapped density }=\frac{\text { Weight of sample }}{\text { tapped volume of powder }}
$$

\section{Angle of repose [14]:}

The frictional force in a loose powder can be measured by the angle of repose $(\theta)$. It is defined as, the maximum angle possible between the surface of the pile of the powder and the horizontal plane. If more powder is added to the pile, it slides down the sides of the pile until the mutual friction of the particles producing a surface angle $\theta$, is in equilibrium with the gravitational force.

The fixed funnel method was employed to measure the angle of repose. A funnel was secured with its tip at a given height $(h)$, above a graph paper that is placed on a flat horizontal surface. The blend was carefully pored through the funnel until the apex of the conical pile just touches the tip of the funnel. The radius (r) of the base of the conical pile was measured. The angle of repose $(\theta)$ was calculated using the following formula:

$$
\operatorname{Tan} \theta=\frac{\text { Height of the pile }}{\text { radius of the base of the pile }}
$$




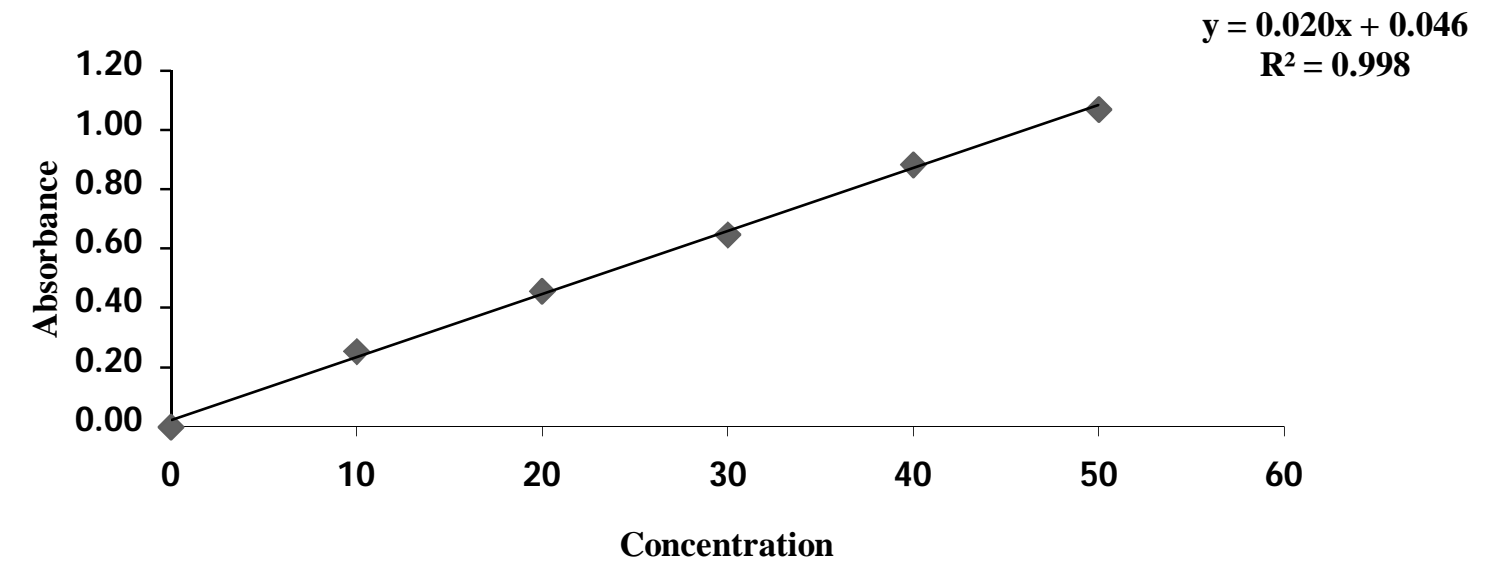

Fig 1: standard calibration curve of Famotidine in $0.1 \mathrm{~N} \mathrm{HCl}$

Table 1: Composition of Famotidine floating tablets

\begin{tabular}{cccccc}
\hline Ingredients (mg/tablet) & F1 & F2 & F3 & F4 & F5 \\
\hline Famotidine & 200 & 200 & 200 & 200 & 200 \\
Hibiscus mucilage & 20 & 25 & 30 & 35 & 40 \\
HPMC K100M & 40 & 35 & 30 & 25 & 20 \\
MCC & 60 & 60 & 60 & 60 & 60 \\
Sodium bicarbonate & 60 & 60 & 60 & 60 & 60 \\
Citric acid & 10 & 10 & 10 & 10 & 10 \\
Magnesium stearate & 5 & 5 & 5 & 5 & 5 \\
Talc & 5 & 5 & 5 & 5 & 5 \\
Total weight & 400 & 400 & 400 & 400 & 400 \\
\hline
\end{tabular}

where $\theta=\tan ^{-1}(\mathrm{~h} / \mathrm{r}) \theta=$ angle of repose

\section{Carr's index (\%) [14]:}

The compressibility index (carr's index) is a measure of the propensity of a powder to be compressed. It is determined from the bulk and tapped densities. In theory, the less compressible a material the more flowable it is. As such, it is measures of the relative importance of interparticulate interactions. In a free flowing powder, such interactions are generally less significant, and the bulk and tapped densities will be closer in value. For poorer flowing materials, there are frequently greater inter particle interactions and a greater difference between the bulk and tapped densities will be observed. These differences are reflected in the carr's index which is calculated using the following formulas:

$$
\text { Carr's Index }(\%)=\frac{\text { Tappeddensity- Bulkdensity }}{\text { Tappeddensity }} \text { X100 }
$$

\section{Hausner's ratio [14]:}

Hausner's ratio is an indirect index of ease of powder flow. It is calculated by the following formula.

$$
\text { Hausner' s Ratio }=\frac{\text { Tapped density }}{\text { Bulk density }}
$$

\section{Post compression parameters [15-21]:}

\section{Tablet thickness and diameter:}

Thickness and diameter of tablets were important for uniformity of tablet size. Thickness and diameter were measured using Vernier calipers. 


\section{Hardness:}

This test is used to check the hardness of a tablet which may undergo chipping or breakage during storage, transportation and handling. In this five tablets were selected at random and the hardness of each tablet was measured with Pfizer hardness tester. The hardness is usually measured in terms of $\mathrm{kg} / \mathrm{cm}^{2}$.

\section{Uniformity of weight:}

This test is performed to maintain the uniformity of weight of each tablet which should be in the prescribed range, this is done by sampling and weighing 20 tablets at random and average weight is calculated. Not more than two of the individual weights deviate from the average weight by more than the percentage show in the table.

\section{Friability test:}

The friability of tablets was determined using Roche friabilator. It is expressed in percentage (\%). Ten tablets were initially weighed $\left(\mathrm{W}_{\text {initial }}\right)$ and transferred into friabilator. The friabilator was operated at $25 \mathrm{rpm}$ for $4 \mathrm{~min}$ or run up to 100 revolutions. The tablets were weighed again $\left(\mathrm{W}_{\text {final }}\right)$. The $\%$ friability was then calculated by using following formula

$$
F=\frac{W_{\text {initial }}-W_{\text {final }}}{W_{\text {initial }}} \times 100
$$

$\%$ Friability of tablets less than $1 \%$ are considered acceptable.

\section{Content uniformity:}

Tablet containing $400 \mathrm{mg}$ of drug is dissolved in $100 \mathrm{ml}$ of $0.1 \mathrm{~N} \mathrm{HCl}$ taken in volumetric flask. The drug is allowed to dissolve in the solvent. The solution was filtered, $1 \mathrm{ml}$ of filtrate was taken in $100 \mathrm{ml}$ volumetric flask and diluted to mark with $0.1 \mathrm{~N} \mathrm{HCl}$ and analyzed spectroscopically at $242 \mathrm{~nm}$. The concentration of Famotidine in $\mathrm{mg} / \mathrm{ml}$ was obtained by using standard calibration curve of the drug. Drug content studies were carried out in triplicate for each formulation batch.

\section{In vitro floating study:}

The time taken by the tablet to emerge onto the surface of the medium after adding to the dissolution medium is called Buoyancy lag time (BLT). Duration of time by which the dosage form constantly emerges on surface of medium called Total floating time (TFT).

Both BLT \& TFT were determined by placing the tablet in $900 \mathrm{ml}$ of simulated gastric fluid without pepsin, at $\mathrm{pH} 1.2$, temperature $37 \pm 0.5^{\circ} \mathrm{C}$, paddle rotation at 50rpm using stopwatch.

\section{In vitro dissolution studies:}

In vitro release studies were carried out using USP dissolution testing apparatus II (paddle type). The dissolution test was performed using $900 \mathrm{ml}$ of simulated gastric fluid $(\mathrm{pH} 1.2)$, at $37 \pm 0.5^{\circ} \mathrm{C}$ and $75 \mathrm{rpm}$. Samples of $5 \mathrm{ml}$ were withdrawn at predetermined time intervals, filtered and replaced with $5 \mathrm{ml}$ of fresh dissolution medium. The collected samples were suitably diluted with dissolution fluid and were analyzed at $242 \mathrm{~nm}$ by using a UV spectrophotometer. Each dissolution study was performed for three times and the mean values were taken.

\section{Dissolution kinetics [22, 23]:}

To analyze the mechanism of release and release rate kinetics of the dosage form, the data obtained were fitted into Zero order, First order, Higuchi matrix, Peppas and Hixson-Crowell model using PCP-DISSOv3 software. Based on the r-value, the best-fit model was selected.

\section{Zero order kinetics:}

Drug dissolution from pharmaceutical dosage forms that do not disaggregate and release the drug slowly can be represented by the equation:

$$
\mathbf{Q}_{\mathbf{t}}=\mathbf{K}_{\mathbf{0}} \mathbf{t}+\mathbf{Q}_{\mathbf{0}}
$$

Where $\mathrm{Q}_{\mathrm{t}}=$ amount of drug dissolved in time $\mathrm{t}$.

$\mathrm{Q}_{0}=$ initial amount of the drug in the solution and

$\mathrm{K}_{0}=$ zero order release constant.

To study the release kinetics, data obtained from in vitro drug release studies were plotted as cumulative amount of drug released versus time.

\section{First order kinetics:}

Assuming that the exposed surface area of a tablet decrease exponentially with time during dissolution process and suggested that drug release from most of the slow release tablets could be described adequately by apparent first order kinetics.

The release of the drug which followed first order kinetics can be expressed by the equation:

$$
\log \mathrm{C}=\log \mathrm{C}_{\mathbf{0}} \ldots . . \mathrm{Kt} / \mathbf{2 . 3 0 3}
$$

Where $\mathrm{C}_{0}=$ initial concentration of drug, $\mathrm{k}=$ first order rate constant

The data obtained are plotted as log cumulative percentage of drug remaining versus time which would yield a straight line with a slope of - K/2.303. 


\section{Higuchi model:}

The first example of a mathematical model aimed to describe drug release from a matrix system was proposed by Higuchi in 1961. : It defines a linear dependence of the active fraction released per unit of surface $(\mathrm{Q})$ on the surface root of time.

$$
Q=K^{2} t^{1 / 2}
$$

Where, $\mathrm{K}^{2}$ is release rate constant

The data obtained were plotted as cumulative percentage drug release versus square root of time.

\section{Hixson-Crowell model:}

Hixson and Crowell derived the equation -

$$
\mathbf{W}_{0}{ }^{1 / 3}-W_{t}^{1 / 3}=\kappa \mathbf{t}
$$

Where $\mathrm{W}_{0}=$ initial amount of drug

$\mathrm{W}_{\mathrm{t}}=$ remaining amount of drug at time $\mathrm{t}$

$\kappa=$ constant representing surface-volume relation.

The equation describes the release from systems where there is a change in surface area and diameter of particles or tablets. To study the release kinetics, data obtained from in vitro drug release studies were plotted as cube root of drug percentage remaining in matrix versus time.

\section{Korsmeyer and Peppas release model:}

In order to define a model, which would represent a better fit for the formulation dissolution data was further analyzed by Peppas \& Korsmeyer equation

\section{$M t \backslash M \alpha=K . t^{n}$}

Where $\mathrm{Mt}=$ amount of drug released at time $\mathrm{t}$ and

$\mathrm{M} \alpha=$ amount released at Time $\alpha$

$\mathrm{K}=$ kinetic constant and

$\mathrm{n}=$ diffusional exponent.

To study the release kinetics, data obtained from in vitro drug release studies were plotted as $\log$ cumulative percentage drug release versus log time. In this model, the value of ' $n$ ' characterizes the release mechanism of drug.

\section{Stability studies [24]:}

The purpose of stability testing is to provide evidence on how the quality of a drug substance or drug product varies with time under influence of a variety of environmental factors such as temperature, humidity and light, and enables recommended storage conditions, re-test periods and shelf to be established. In the present study, stability studies were carried out at $40^{\circ} \mathrm{C}$ and $75 \% \mathrm{RH}$ for a specific time period up to 4 weeks for optimized formulation. For stability study, the tablets were sealed in aluminium packaging coated inside with polyethylene. These sample containers were placed in desiccator maintained at $75 \% \mathrm{RH}$. The samples were analyzed for appearance, hardness, and drug content.

\section{RESULTS AND DISCUSSION Drug - Excipient compatibility study:}

This study confirmed no interaction between the drug and excipients i.e., the physical appearance of drugexcipient mixture, $R_{f}$ value and $\lambda_{\max }$ of drug observed for 4 weeks were found to be almost similar with the initial observations. Hence, it can be concluded that the drug Famotidine was found to be compatible with the excipients used in the designed formulation. The observations of drug-excipient compatibility study are tabulated in Table $2 \& 3$.

\section{Drug - Excipient compatibility study by FTIR study}

Based on the FTIR interpretation results, all the major drug peaks were identified when compared with the physical mixture of drug and polymer/excipients which ensured that there was no any chemical interaction between them. The significant peaks (functional groups) and FTIR spectra of drug and drug-polymer mixture are shown in Table 4 and Fig 2, 3, 4 and 5.

\section{Pre-compression parameters:}

The values of bulk density were found to be in the range from $0.372 \mathrm{gm} / \mathrm{cm}^{3}$ to $0.394 \mathrm{gm} / \mathrm{cm}^{3}$ and tapped density from $0.444 \mathrm{gm} / \mathrm{cm}^{3}$ to $0.456 \mathrm{gm} / \mathrm{cm}^{3}$. The angle of repose values were found to be in the range from $23.45^{\circ}$ to $28.15^{\circ}$. This indicates good flow property of the blend. Compressibility index value ranges between $11.65 \%$ to $17.54 \%$ indicating that the powder blend have the required flow property for direct compression. The values of Hausner's ratio were range from 1.131 to 1.212. The values are shown in Table 5 .

\section{Post-compression parameters}

Tablets mean thickness were almost uniform in all the five formulations and were found to be in the range of $3.38 \mathrm{~mm}$ to $3.41 \mathrm{~mm}$. The measured hardness of tablets of each batch ranged between $4.7 \mathrm{~kg} / \mathrm{cm}^{2}$ to $4.8 \mathrm{~kg} / \mathrm{cm}^{2}$. This ensures good handling characteristics of all batches. The $\%$ friability was less than $1 \%$ in all formulations ensuring that the tablets were mechanically stable. All the tablets passed weight variation test as the \% weight variation was within the pharmacopoeial limits of $\pm 5 \%$ of the weight.

The weights of all the tablets were found to be uniform with low standard deviation. The percentage of drug content was found to be in between $96.13 \%$ to $99.67 \%$ 
Table 2: Drug-Excipient compatibility study by Physical observation

\begin{tabular}{cccc} 
Ingredients & \multicolumn{3}{c}{ Observations at 0 day } \\
\cline { 2 - 4 } Drug & Appearance & $\mathbf{R}_{\mathbf{f}}$ & $\boldsymbol{\lambda}_{\max }(\mathbf{n m})$ \\
Drug \pm HPMC K 1OOM & Buff & 0.375 & 242 \\
Drug \pm HPMC K 15M & White & 0.372 & 242 \\
Drug \pm Hibiscus mucilage & White & 0.374 & 242 \\
Drug \pm Xanthan gum & Light green & 0.373 & 242 \\
Drug \pm Guar gum & White creamy & 0.376 & 242 \\
Drug \pm Carbopol 934P & Light yellow & 0.375 & 242 \\
Drug \pm MCC & White & 0.377 & 242 \\
Drug \pm Sodium bicarbonate & White & 0.374 & 242 \\
Drug \pm Citric acid & White & 0.371 & 242 \\
& Buff & 0.368 & 242
\end{tabular}

Table 3: Drug-Excipient compatibility study

\begin{tabular}{|c|c|c|c|c|c|c|c|c|c|c|c|c|}
\hline \multirow{2}{*}{ Ingredients } & \multicolumn{3}{|c|}{$1^{\text {st }}$ week } & \multicolumn{3}{|c|}{$2^{\text {nd }}$ week } & \multicolumn{3}{|c|}{$3^{\text {rd }}$ week } & \multicolumn{3}{|c|}{$4^{\text {th }}$ week } \\
\hline & $\mathbf{A}$ & $\mathbf{R}_{f}$ & $\lambda_{\max }$ & $\mathbf{A}$ & $\mathbf{R}_{f}$ & $\lambda_{\max }$ & $\mathbf{A}$ & $\mathbf{R}_{f}$ & $\lambda_{\max }$ & $\mathbf{A}$ & $\mathbf{R}_{f}$ & $\lambda_{\max }$ \\
\hline Drug & $\mathrm{NC}$ & 0.374 & $\mathrm{NC}$ & $\mathrm{NC}$ & 0.374 & $\mathrm{NC}$ & $\mathrm{NC}$ & 0.372 & $\mathrm{NC}$ & $\mathrm{NC}$ & 0.371 & $\mathrm{NC}$ \\
\hline $\begin{array}{c}\text { Drug }+ \\
\text { HPMC K } \\
\text { 1OOM }\end{array}$ & $\mathrm{NC}$ & 0.372 & $\mathrm{NC}$ & $\mathrm{NC}$ & 0.370 & $\mathrm{NC}$ & $\mathrm{NC}$ & 0.370 & $\mathrm{NC}$ & $\mathrm{NC}$ & 0.371 & $\mathrm{NC}$ \\
\hline $\begin{array}{c}\text { Drug + } \\
\text { HPMC K } \\
\text { 15M }\end{array}$ & $\mathrm{NC}$ & 0.374 & $\mathrm{NC}$ & $\mathrm{NC}$ & 0.375 & $\mathrm{NC}$ & $\mathrm{NC}$ & 0.373 & $\mathrm{NC}$ & $\mathrm{NC}$ & 0.373 & $\mathrm{NC}$ \\
\hline $\begin{array}{c}\text { Drug + } \\
\text { Hibiscus } \\
\text { mucilage }\end{array}$ & $\mathrm{NC}$ & 0.373 & $\mathrm{NC}$ & $\mathrm{NC}$ & 0.373 & $\mathrm{NC}$ & $\mathrm{NC}$ & 0.372 & $\mathrm{NC}$ & $\mathrm{NC}$ & 0.371 & $\mathrm{NC}$ \\
\hline $\begin{array}{c}\text { Drug + } \\
\text { Xanthan gum }\end{array}$ & $\mathrm{NC}$ & 0.376 & $\mathrm{NC}$ & $\mathrm{NC}$ & 0.375 & $\mathrm{NC}$ & $\mathrm{NC}$ & 0.376 & $\mathrm{NC}$ & $\mathrm{NC}$ & 0.374 & $\mathrm{NC}$ \\
\hline $\begin{array}{c}\text { Drug + } \\
\text { Guar gum }\end{array}$ & $\mathrm{NC}$ & 0.375 & $\mathrm{NC}$ & $\mathrm{NC}$ & 0.373 & $\mathrm{NC}$ & $\mathrm{NC}$ & 0.374 & $\mathrm{NC}$ & $\mathrm{NC}$ & 0.372 & $\mathrm{NC}$ \\
\hline $\begin{array}{c}\text { Drug + } \\
\text { Carbopol } \\
\text { 934P }\end{array}$ & $\mathrm{NC}$ & 0.377 & $\mathrm{NC}$ & $\mathrm{NC}$ & 0.375 & $\mathrm{NC}$ & $\mathrm{NC}$ & 0.375 & $\mathrm{NC}$ & $\mathrm{NC}$ & 0.374 & $\mathrm{NC}$ \\
\hline $\begin{array}{c}\text { Drug + } \\
\text { MCC }\end{array}$ & $\mathrm{NC}$ & 0.374 & $\mathrm{NC}$ & $\mathrm{NC}$ & 0.374 & $\mathrm{NC}$ & $\mathrm{NC}$ & 0.373 & $\mathrm{NC}$ & $\mathrm{NC}$ & 0.372 & $\mathrm{NC}$ \\
\hline $\begin{array}{c}\text { Drug } \\
\text { +Sodium } \\
\text { bicarbonate }\end{array}$ & $\mathrm{NC}$ & 0.370 & $\mathrm{NC}$ & $\mathrm{NC}$ & 0.371 & $\mathrm{NC}$ & $\mathrm{NC}$ & 0.370 & $\mathrm{NC}$ & $\mathrm{NC}$ & 0.369 & $\mathrm{NC}$ \\
\hline $\begin{array}{c}\text { Drug + } \\
\text { Citric acid }\end{array}$ & $\mathrm{NC}$ & 0.368 & $\mathrm{NC}$ & $\mathrm{NC}$ & 0.368 & $\mathrm{NC}$ & $\mathrm{NC}$ & 0.368 & $\mathrm{NC}$ & $\mathrm{NC}$ & 0.367 & $\mathrm{NC}$ \\
\hline \multicolumn{13}{|c|}{$\mathrm{A}=$ Appearance, $\mathrm{NC}=$ No change } \\
\hline
\end{tabular}


Nagarjuna Paleti / J Compr Phar 2016;3(3):99-114

Table 4: FTIR spectra - Interpretation \& Comparison

\begin{tabular}{cccccc}
\hline $\begin{array}{c}\text { Functional } \\
\text { groups }\end{array}$ & $\begin{array}{c}\text { Stretching/ } \\
\text { Deformation }\end{array}$ & \multicolumn{4}{c}{ FTIR significant peaks } \\
\cline { 3 - 6 } & & $\begin{array}{c}\text { Pure } \\
\text { drug } \\
\left(\mathbf{c m}^{-1}\right)\end{array}$ & $\begin{array}{c}\text { Drug }+ \\
\text { HPMC } \\
\text { K100M } \\
\left(\mathbf{c m}^{-1}\right)\end{array}$ & $\begin{array}{c}\text { Drug+ Hibiscus } \\
\text { mucilage } \\
\left(\mathbf{c m}^{-1}\right)\end{array}$ & $\begin{array}{c}\text { Drug + All } \\
\text { Excipients } \\
\left(\mathbf{c m}^{-1}\right)\end{array}$ \\
\hline $\mathrm{C}-\mathrm{N}$ & Stretching & 1225.65 & 1225.59 & 1225.49 & 1225.15 \\
$\mathrm{C}-\mathrm{N}$ & Stretching & 1354.65 & 1354.63 & 1357.63 & 1354.01 \\
\hline $\mathrm{C}-\mathrm{NO}_{2}$ & Stretching & 1391.02 & 1391.14 & 1392.87 & 1382.48 \\
$\mathrm{C}-\mathrm{S}$ & Stretching & 691.53 & 691.70 & 692.09 & 692.06 \\
\hline $\mathrm{C}=\mathrm{C}$ & Stretching & 1617.56 & 1617.75 & 1618.50 & 1616.95 \\
\hline $\mathrm{CH}_{3}$ & Stretching & 2942.96 & 2945.27 & 2943.40 & 2943.04 \\
\hline $\mathrm{CH}_{3}$ & Deformation & 1436.22 & 1435.62 & 1432.20 & 1433.25 \\
\hline $\mathrm{N}-\mathrm{H}$ & Deformation & 1583.37 & 1584.15 & 1585.56 & 1586.18 \\
\hline $\mathrm{CH}_{3}-\mathrm{N}$ & Stretching & 2782.24 & 2779.76 & 2782.73 & 2781.95 \\
\hline
\end{tabular}

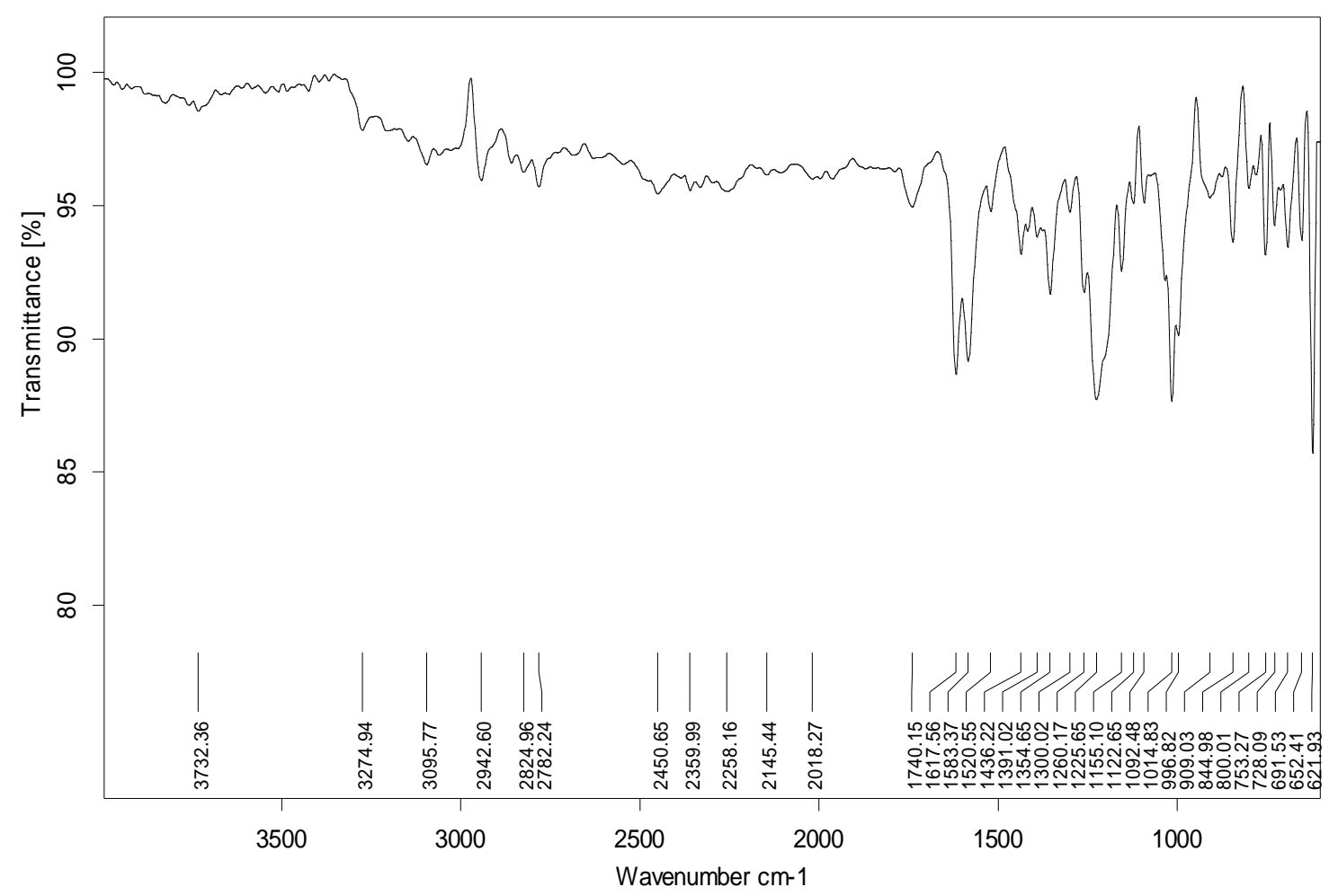

Fig2: FTIR spectra of Famotidine 
Nagarjuna Paleti / J Compr Phar 2016;3(3):99-114

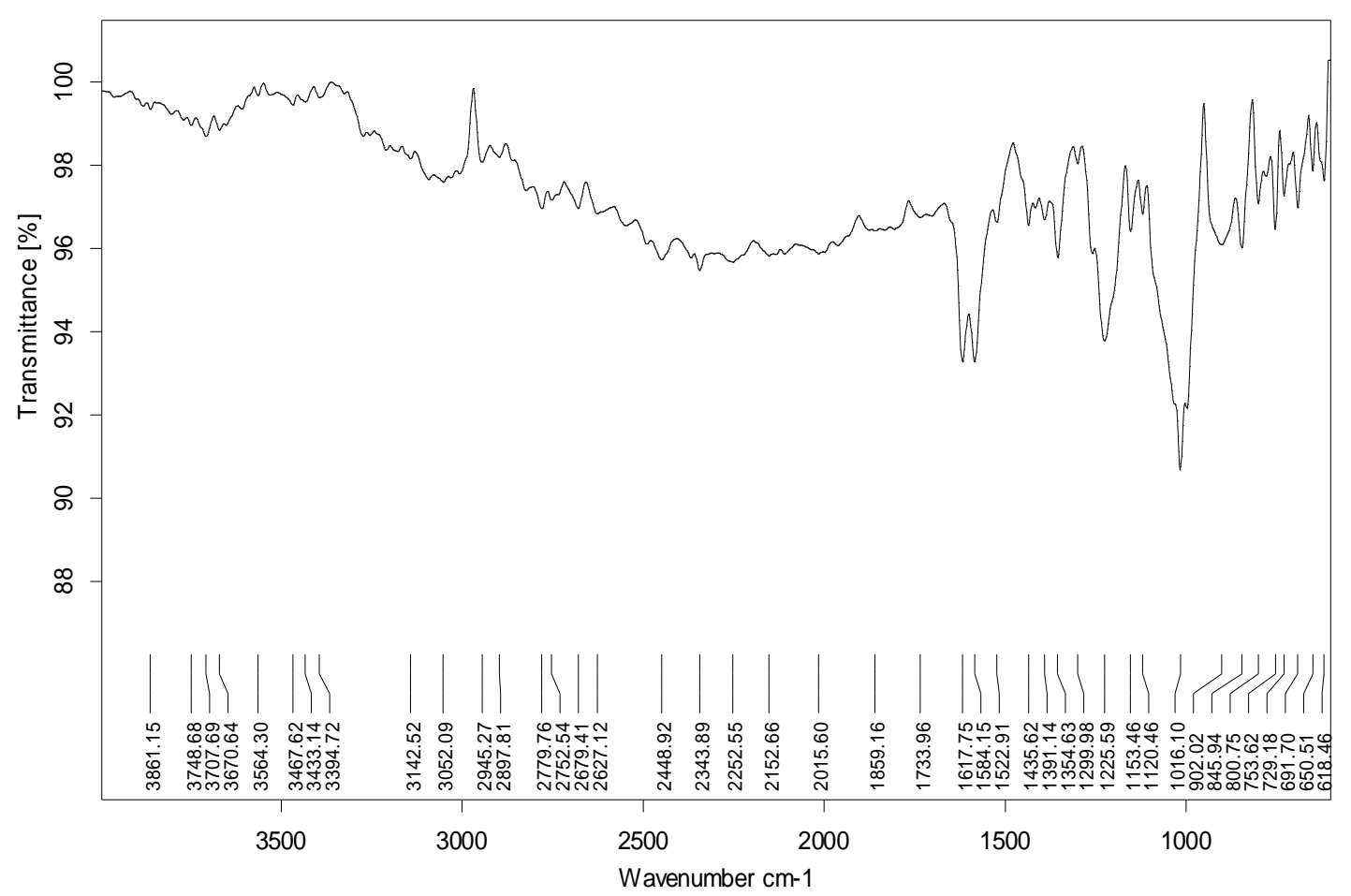

Fig 3: FTIR spectra of Famotidine and HPMC K100M

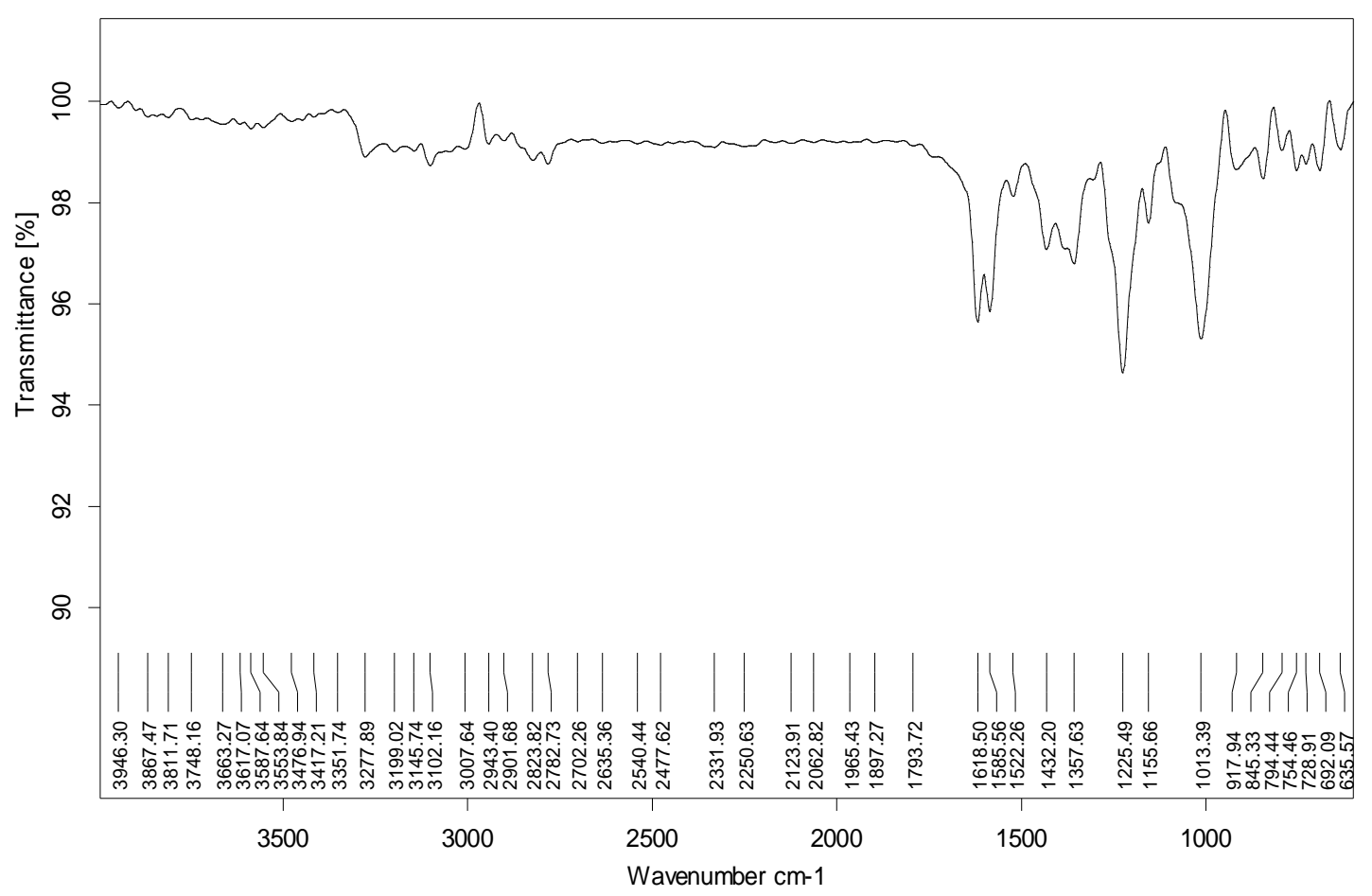

Fig 4: FTIR spectra of Famotidine and Hibiscus mucilage 


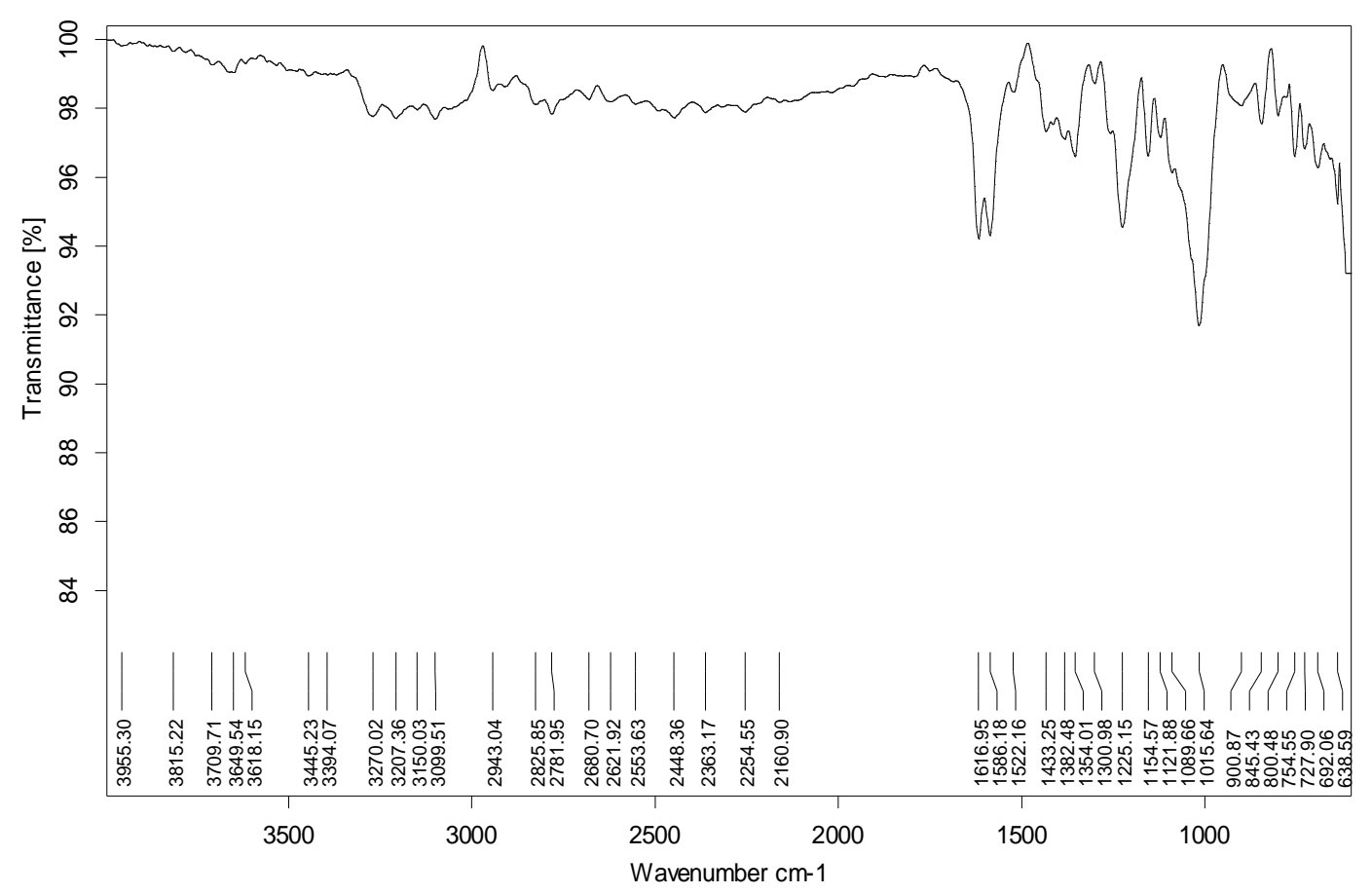

Fig 5: FTIR spectra of Famotidine and All Excipients

which was within acceptable limits. The results are shown in Table 6.

\section{In vitro release study:}

Dissolution apparatus USP II paddle method was used to carry out in vitro drug release studies on the prepared batches of floating tablets with a stirring speed of $75 \mathrm{rpm}$; at $37 \pm 0.5^{\circ} \mathrm{C}$ in $900 \mathrm{ml}$ of $(\mathrm{pH} \mathrm{1.2)}$ simulated gastric fluid for $8 \mathrm{hrs}$. The formulation F1 released $92.4 \%$ of drug within $6 \mathrm{hr}$ of the study indicating that the polymer combination is insufficient to control the drug release. Tablet of batch F2, F3, F4 and F5 showed 90\%, 78.6\%, 69.7\% and $61 \%$ at the end of $8 \mathrm{hrs}$ respectively. Formulation F3 containing equal amounts of HPMC K 100M \& Hibiscus mucilage showed better control of drug release and able to release entire amount of drug in $12 \mathrm{hrs}$ than the other formulations and therefore it may be considered as the optimized formulation. It is evident from the in vitro dissolution data that increase in Hibiscus mucilage concentration decreased release rate of the drug. The in vitro dissolution profiles were shown in Fig 6, 7, 8, 9 , and 10.

The results of dissolution data were fitted to various kinetic equations to analyze the release mechanism. All the formulations followed Peppas model and were found to be best fitted in all dissolution profiles having higher correlation coefficient ( $\mathrm{r}$ value). Formulation F5 followed Zero order kinetics.
The ' $n$ ' value of formulations F2, F3, and F4 was ranges between 0.49 to 0.89 indicating that the drug release occurred via non-Fickian diffusion, which shows that the release from initially dry, hydrophilic glassy polymers that swell when added to water and become rubbery show anomalous diffusion as a result of the rearrangement of macromolecular chains. The ' $\mathrm{n}$ ' value of formulation $\mathrm{F} 1$ was 0.36 indicating that the drug release followed Fickian diffusion which depends on diffusion of the drug. The ' $n$ ' value of formulation F5 was 1.44 indicating that the drug release followed super case II transport mechanism due to the erosion of the polymer. The kinetic plots are shown in Fig 11, 12, 13 , and 14.

\section{Stability studies:}

Stability studies were carried out for optimized formulation $\mathrm{F} 3$ at $40^{\circ} \mathrm{C} / 75 \% \mathrm{RH}$ for 30 days. The results of stability studies revealed no change in physical appearance, hardness and drug content indicating the formulation was stable. The results of stability study are shown in table 8 .

\section{CONCLUSION}

Gastro retentive floating tablets of Famotidine was successfully formulated using HPMC K 100M and Hibiscus polysaccharide as a release retardant materials in different concentrations by direct compression technique. 
Table 5: Pre-compression parameters of Famotidine powder mixture

\begin{tabular}{|c|c|c|c|c|c|}
\hline Formulation & $\begin{array}{c}\text { Bulk } \\
\text { Density }\left(\mathrm{g} / \mathrm{cm}^{3}\right)\end{array}$ & $\begin{array}{c}\text { Tapped } \\
\text { Density }\left(\mathrm{g} / \mathrm{cm}^{3}\right)\end{array}$ & $\begin{array}{l}\text { Angle of repose } \\
(\theta)\end{array}$ & Carr's index & $\begin{array}{l}\text { Hausner's } \\
\text { ratio }\end{array}$ \\
\hline F1 & $0.380 \pm 0.020$ & $0.444 \pm 0.026$ & $23.45 \pm 0.010^{\circ}$ & $14.41 \pm 0.021$ & 1.168 \\
\hline F2 & $0.372 \pm 0.019$ & $0.452 \pm 0.030$ & $26.76 \pm 0.021^{\circ}$ & $17.69 \pm 0.030$ & 1.215 \\
\hline F3 & $0.381 \pm 0.021$ & $0.451 \pm 0.028$ & $24.58 \pm 0.015^{\circ}$ & $15.52 \pm 0.027$ & 1.183 \\
\hline F4 & $0.394 \pm 0.025$ & $0.446 \pm 0.032$ & $22.19 \pm 0.030^{\circ}$ & $11.65 \pm 0.036$ & 1.131 \\
\hline F5 & $0.376 \pm 0.026$ & $0.456 \pm 0.036$ & $28.15 \pm 0.028^{\circ}$ & $17.54 \pm 0.029$ & 1.212 \\
\hline
\end{tabular}

Table 6: Post-compression parameters of Famotidine floating tablets

\begin{tabular}{cccccc}
\hline Formulation & Weight variation & $\begin{array}{c}\text { Hardness } \\
\left(\mathrm{kg} / \mathrm{cm}^{2}\right)\end{array}$ & $\begin{array}{c}\text { Thickness } \\
(\mathrm{mm})\end{array}$ & $\begin{array}{c}\text { Friability } \\
(\%)\end{array}$ & $\begin{array}{c}\text { Drug content } \\
(\%)\end{array}$ \\
\hline F1 & $0.403 \pm 0.005$ & $4.75 \pm 0.05$ & $3.38 \pm 0.02$ & $0.74 \pm 0.04$ & 98.72 \\
F2 & $0.402 \pm 0.006$ & $4.78 \pm 0.04$ & $3.39 \pm 0.04$ & $0.72 \pm 0.06$ & 97.78 \\
F3 & $0.402 \pm 0.005$ & $4.82 \pm 0.03$ & $3.40 \pm 0.05$ & $0.45 \pm 0.02$ & 97.07 \\
F4 & $0.401 \pm 0.010$ & $4.83 \pm 0.06$ & $3.39 \pm 0.03$ & $0.56 \pm 0.04$ & 96.13 \\
F5 & $0.403 \pm 0.008$ & $4.78 \pm 0.05$ & $3.41 \pm 0.04$ & $0.61 \pm 0.07$ & 99.67 \\
\hline
\end{tabular}

Table 7: Buoyancy study of Famotidine floating tablets

\begin{tabular}{ccc}
\hline Formulation code & Floating lag time $(\mathrm{min})$ & Total floating time $(\mathrm{hrs})$ \\
\hline F1 & 2.02 & 10 \\
F2 & 1.20 & $>12$ \\
F3 & 4.03 & $>12$ \\
F4 & 6.30 & $>12$ \\
F5 & 6.06 & $>12$ \\
\hline
\end{tabular}

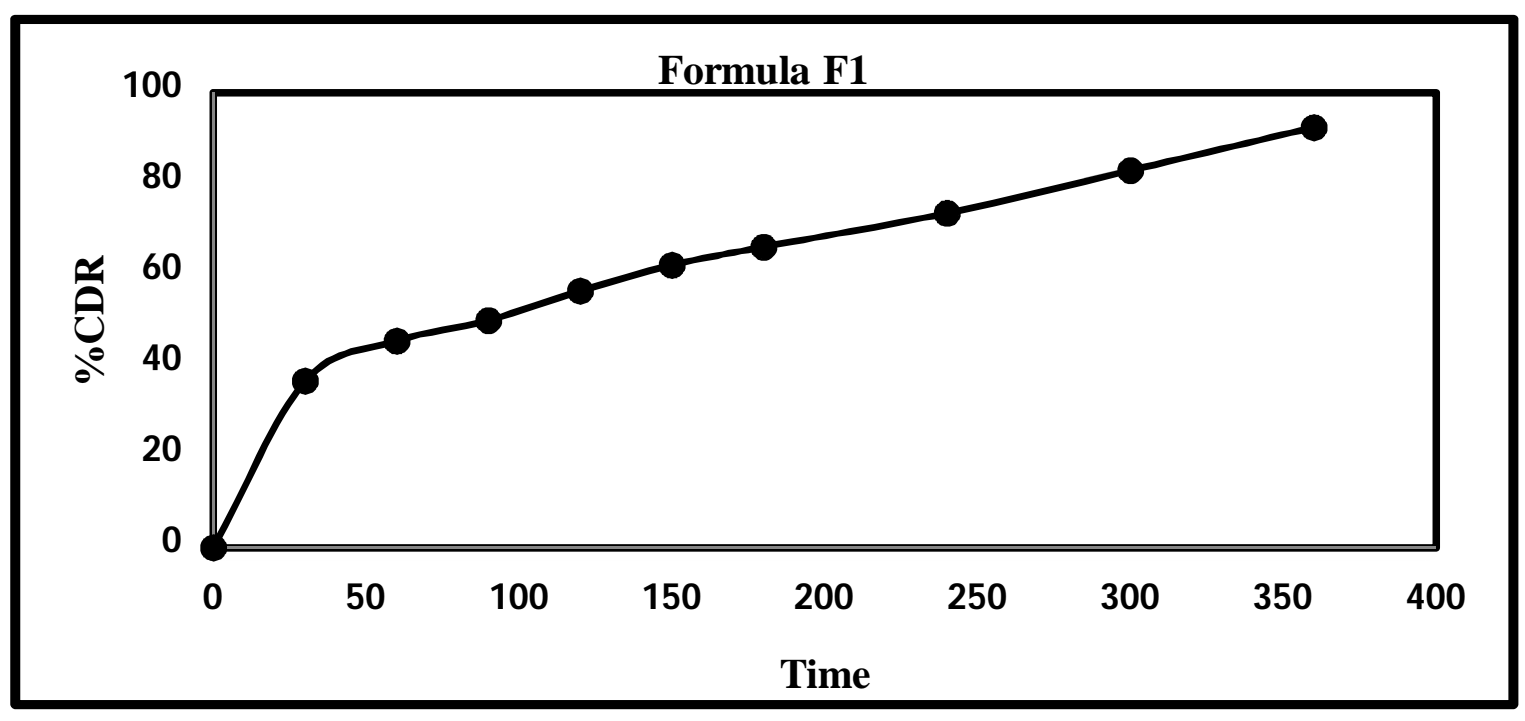

Fig 6: in vitro dissolution study of F1 


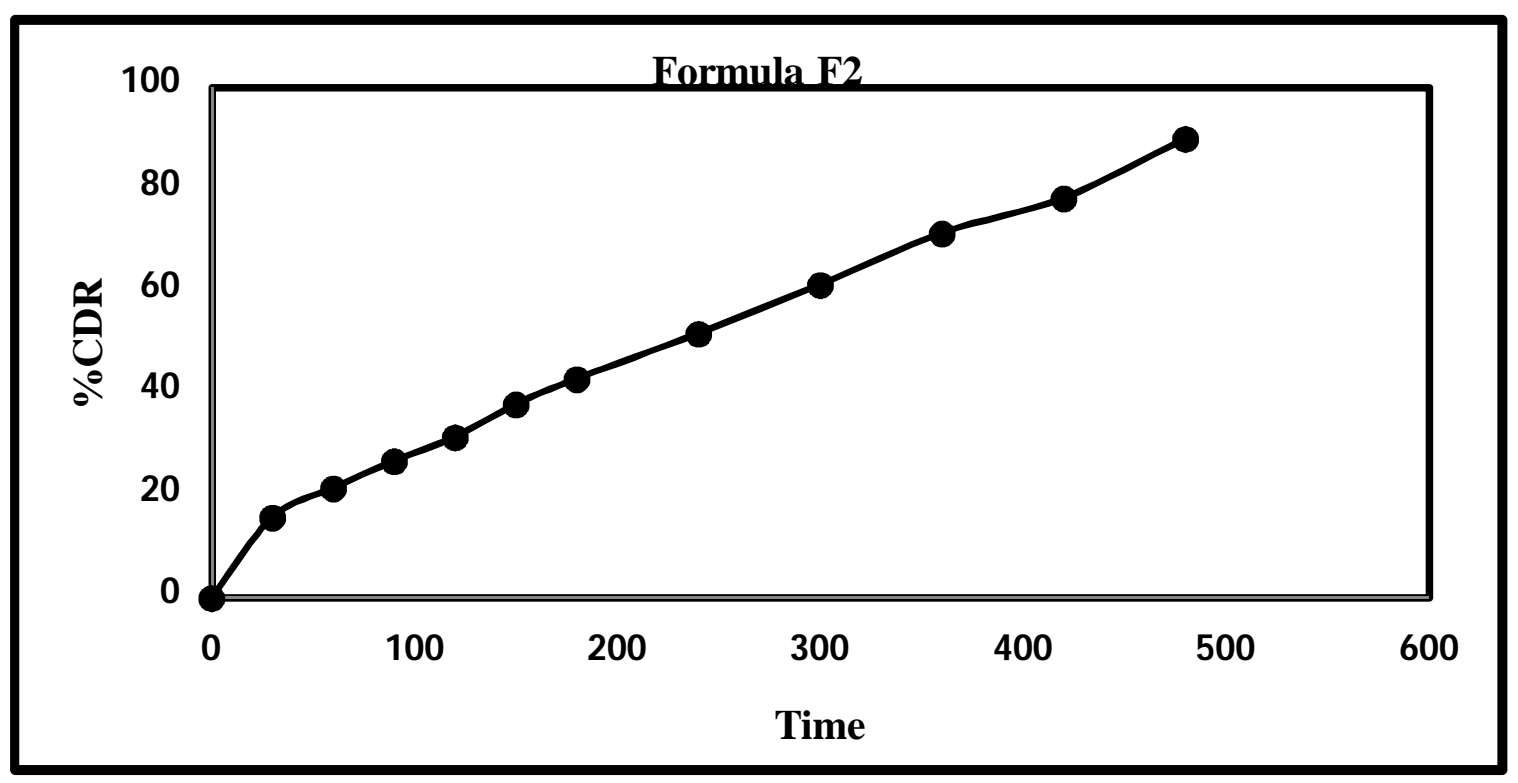

Fig 7: in vitro dissolution study of F2

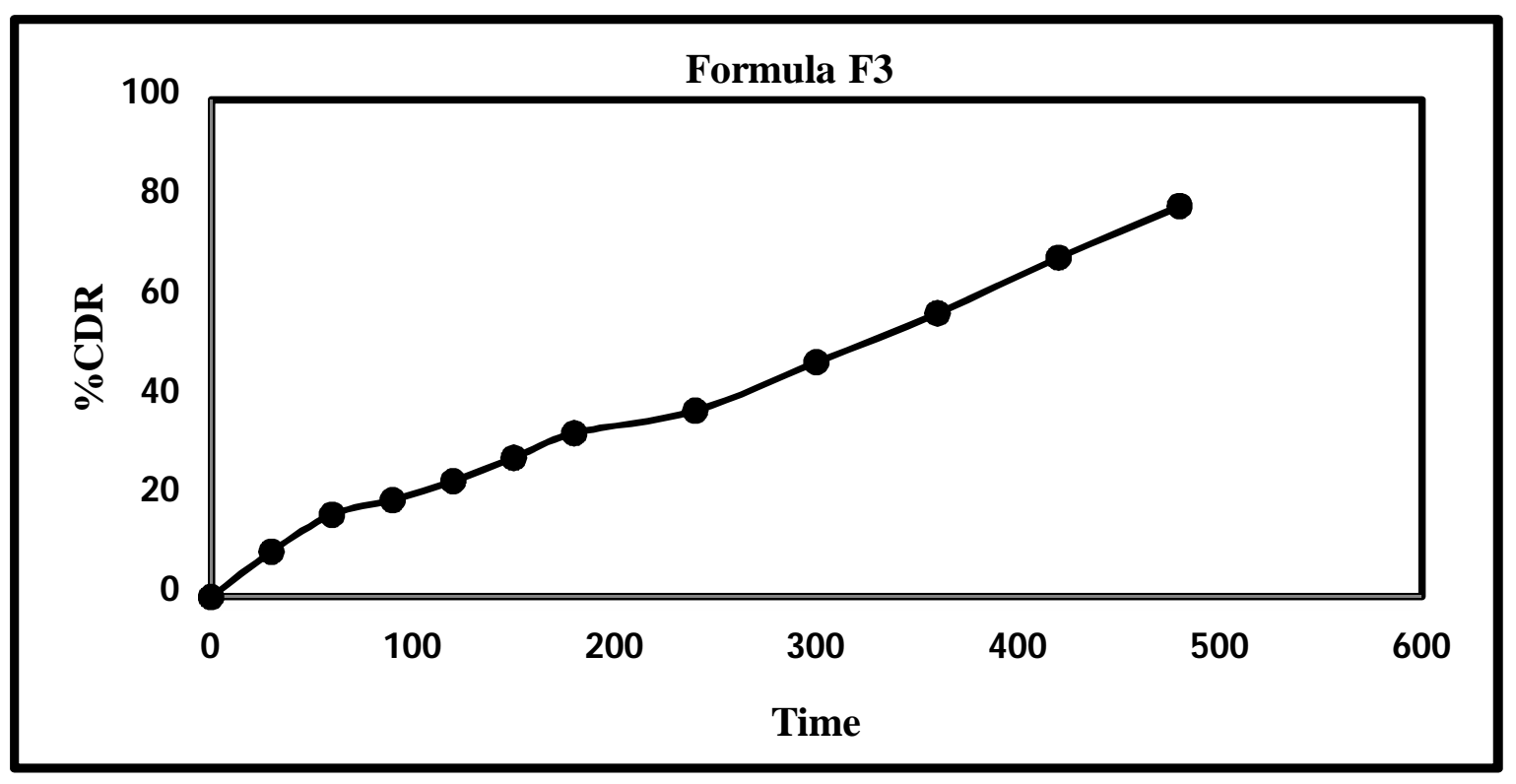

Fig 8: in vitro dissolution study of $\mathrm{F3}$ 
Nagarjuna Paleti / J Compr Phar 2016;3(3):99-114

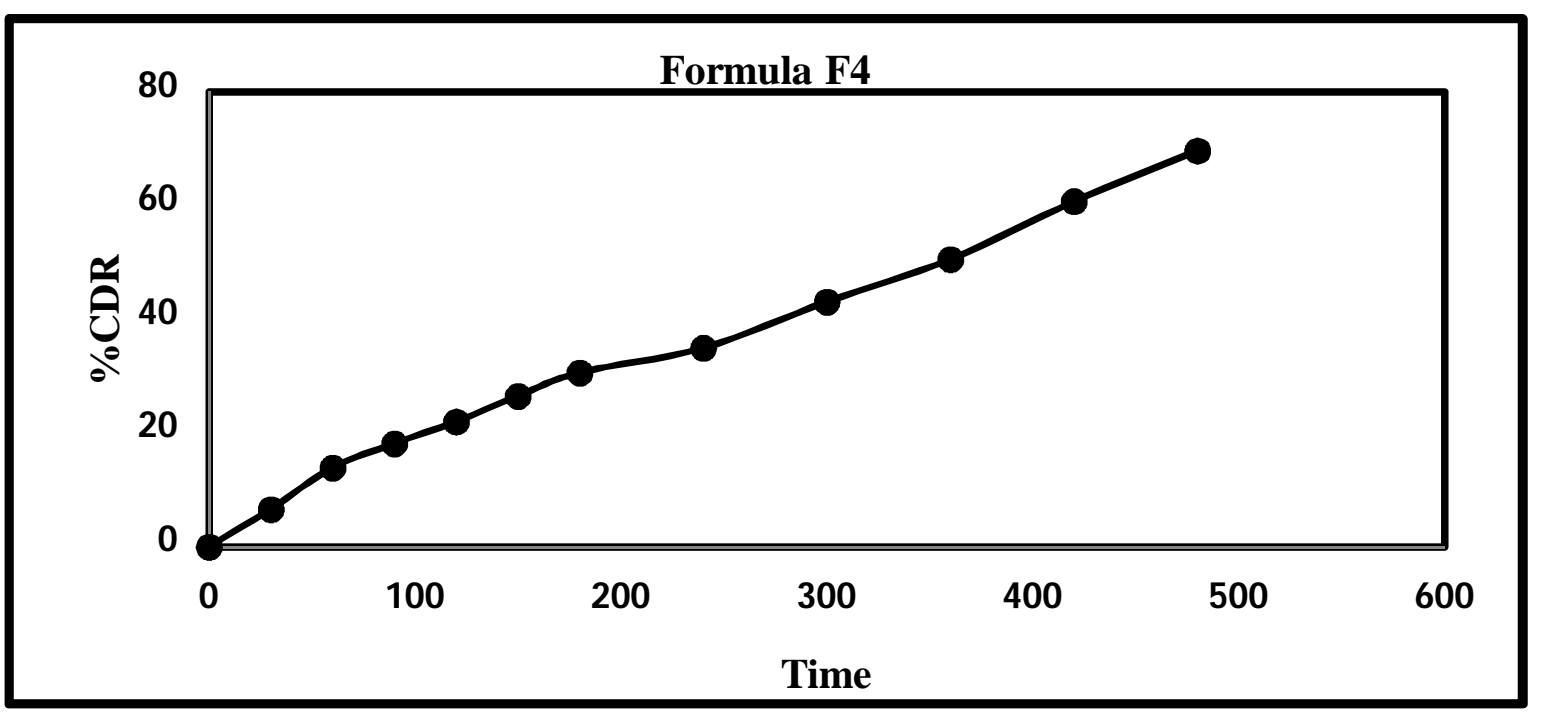

Fig 9: in vitro dissolution rate study of $\mathrm{F} 4$

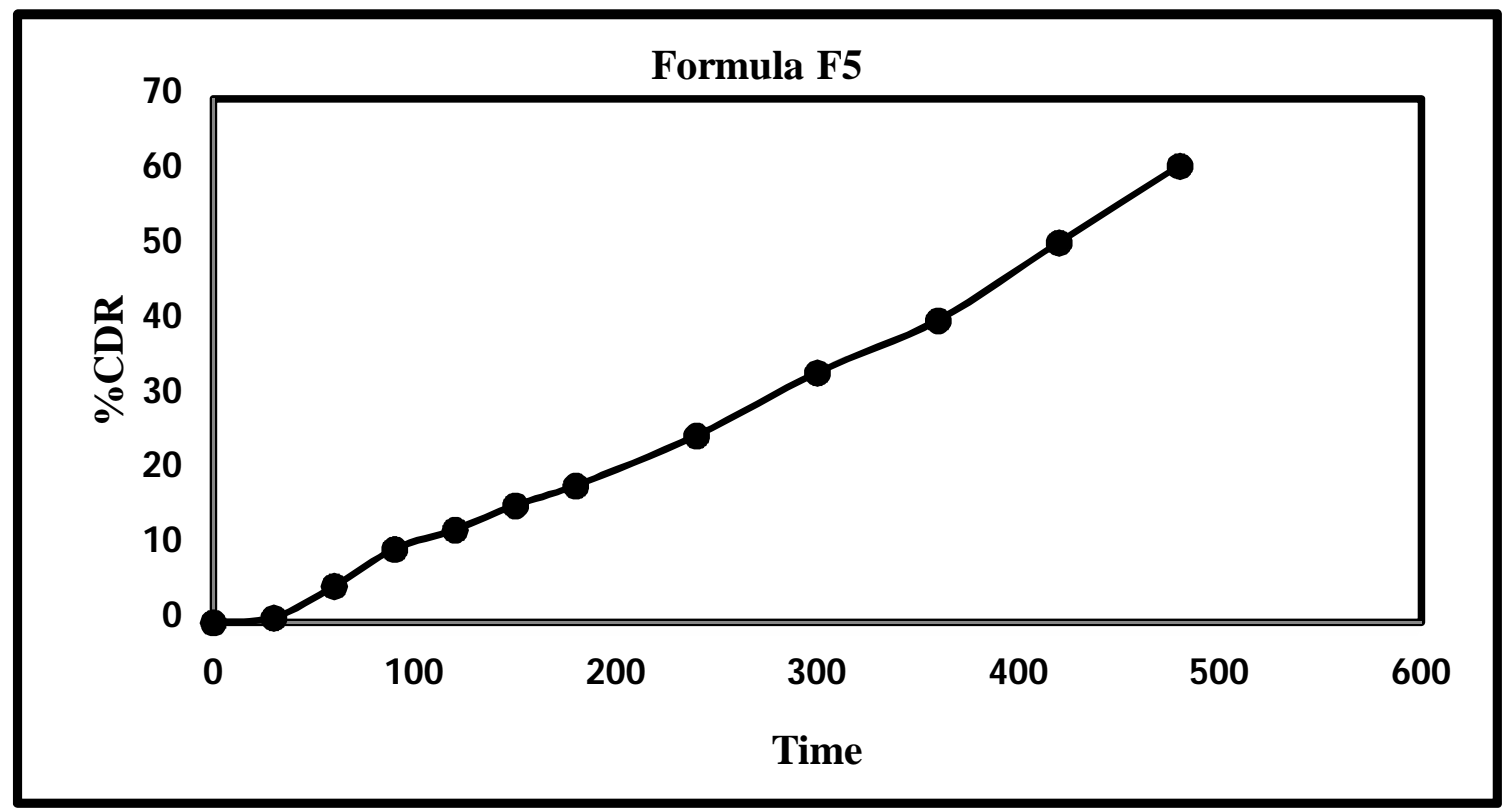

Fig 10: In vitro dissolution study of $\mathrm{F5}$ 


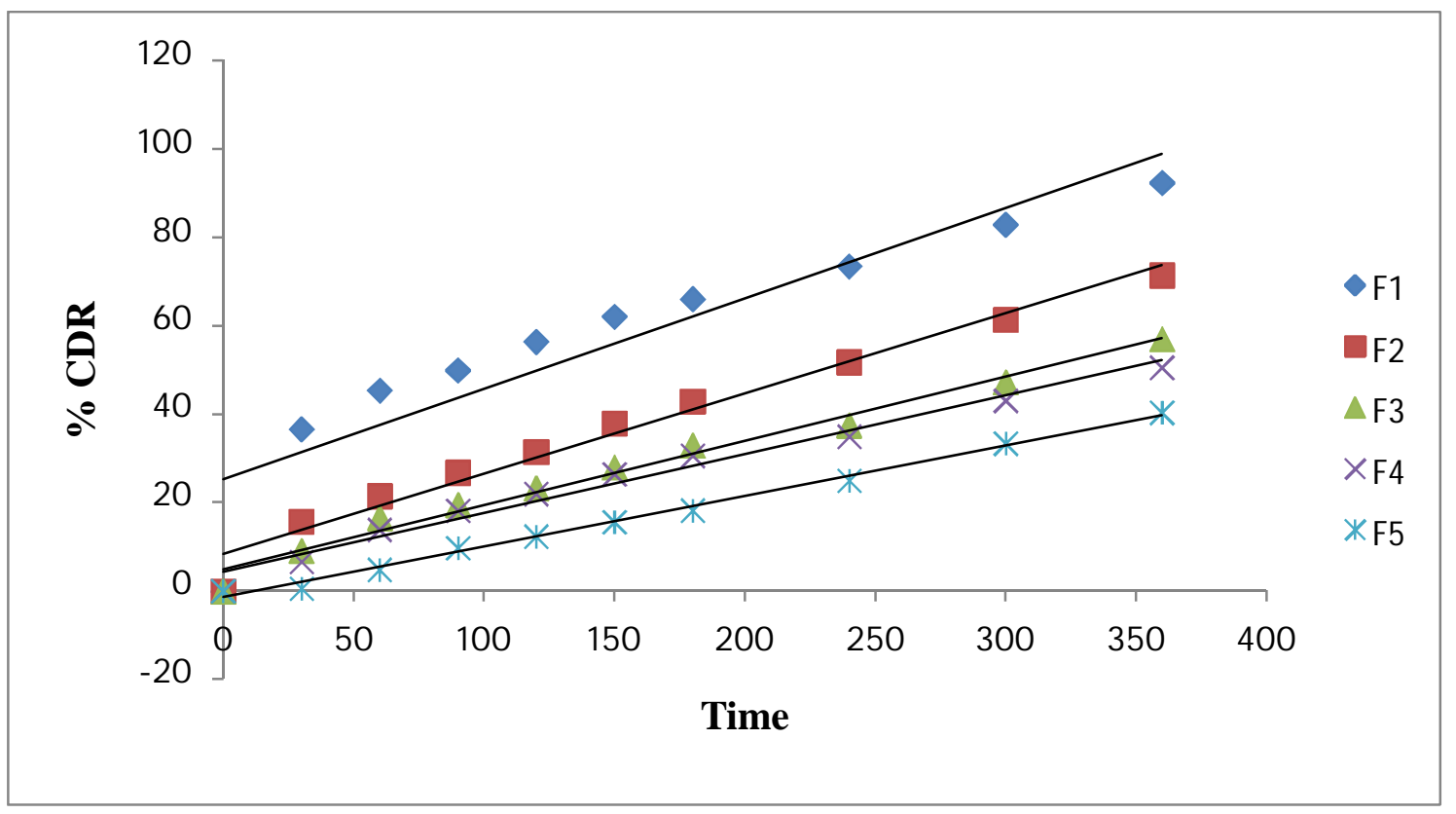

Fig 11: Zero order release kinetics of Famotidine floating tablets

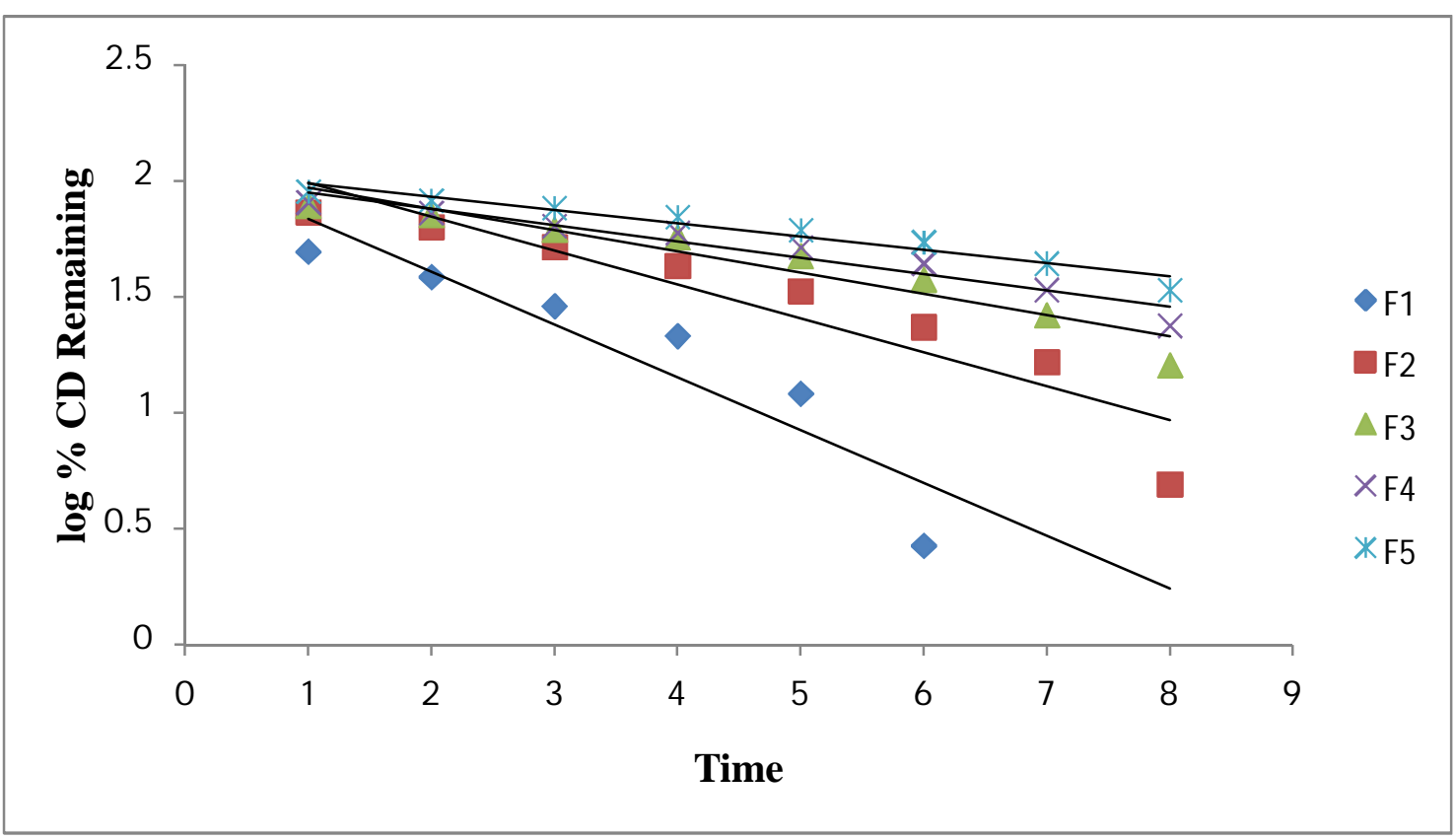

Fig 12: First order release kinetics of Famotidine floating tablets 


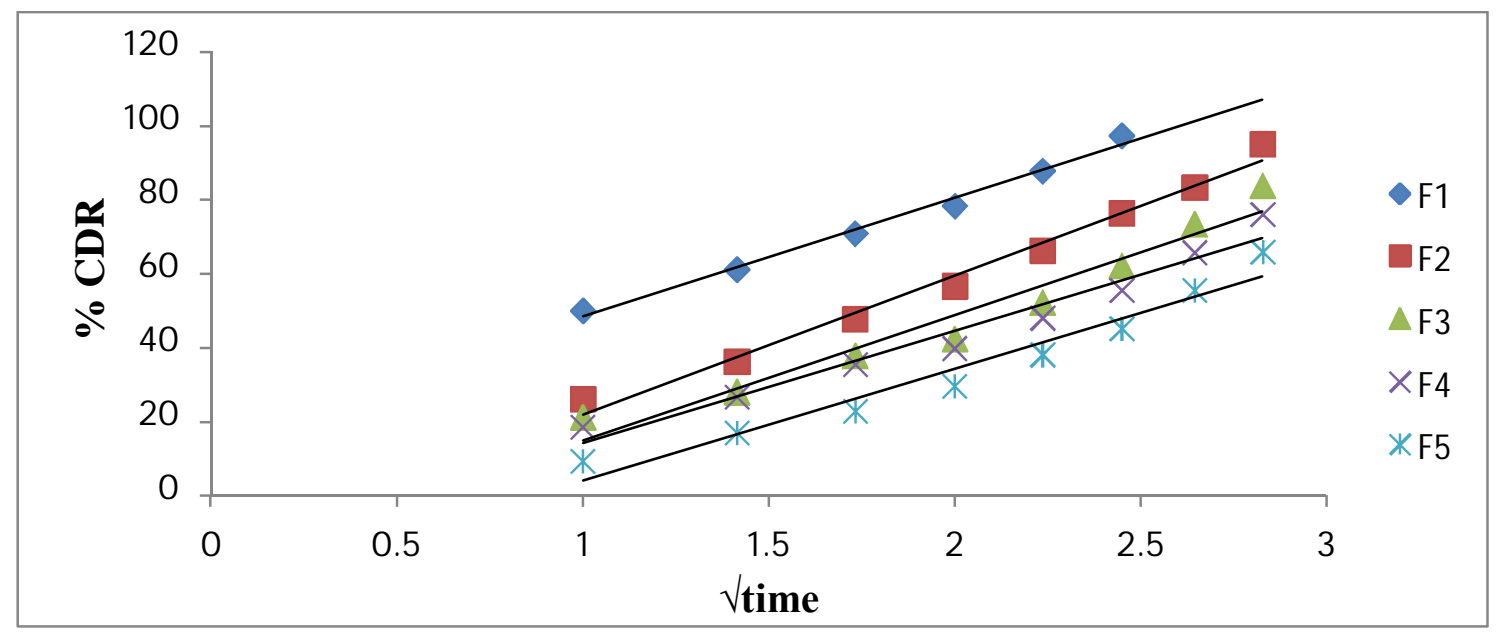

Fig 13: Higuchi matrix release kinetics of Famotidine floating tablets

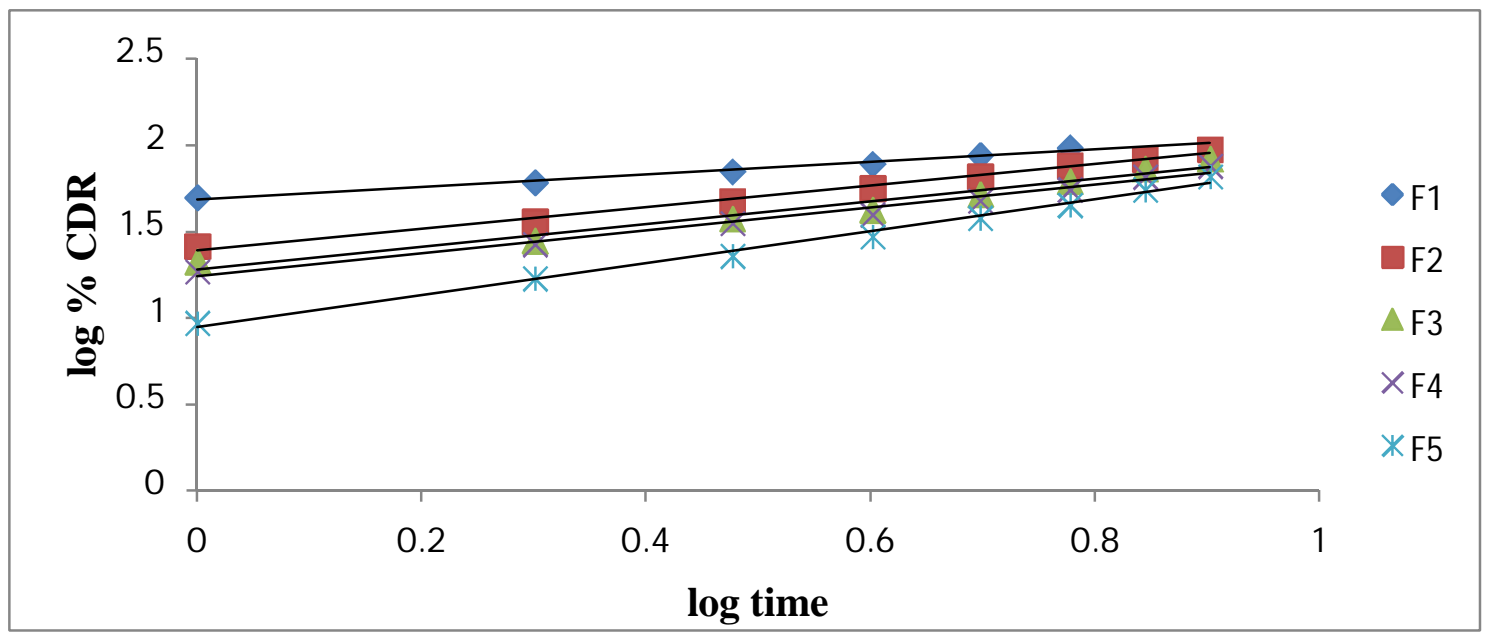

Fig 14: Peppas release kinetics of Famotidine floating tablets

\section{Table 8: Stability study of optimized formulation F3}

Time in weeks Formulation F3

\begin{tabular}{llcc}
\cline { 2 - 4 } & Appearance & $\begin{array}{c}\text { Hardness } \\
\left(\mathbf{K g} / \mathbf{c m}^{\mathbf{2}}\right)\end{array}$ & $\begin{array}{c}\text { Drug content } \\
(\mathbf{\%})\end{array}$ \\
$\mathbf{0}$ & Creamy white & 4.95 & 99.72 \\
$\mathbf{1}$ & Creamy white & 4.95 & 99.55 \\
$\mathbf{2}$ & Creamy white & 4.93 & 99.21 \\
$\mathbf{3}$ & Creamy white & 4.92 & 98.96 \\
$\mathbf{4}$ & Creamy white & 4.92 & 98.71 \\
\hline
\end{tabular}


Drug-Excipient study \& FTIR study confirmed no physical and chemical interaction between the drug and polymer/Excipients used in the formulation. All the tablets were found to be good without any chipping and capping. Formulated tablets gave satisfactory results for various physicochemical evaluations for tablets like Tablet dimensions, Hardness, Friability, Weight variation and content uniformity. The drug content was almost uniform in all the tablets prepared. The low values of standard deviation indicate uniform distribution of drug within the matrices. It is evident from the in vitro dissolution data that increase in Hibiscus mucilage concentration decreased the drug release rate. The results generated in this study showed that the release profile and kinetics of drug release were function of polymer type and polymer concentration. Among all the formulations F3 with equal concentration of HPMC K100M and Hibiscus mucilage showed good controlled release and able to release entire amount of drug in $12 \mathrm{hrs}$ than the other formulations and therefore it may be considered as the optimized formulation. All formulations followed Korsmeyer-Peppas model except formulation F5 which followed zero order kinetics. For formulations F2, F3 and F4 the 'n' was found to between 0.5-1.0 indicate anomalous/non-fickian type release mechanism where the drug release was controlled by both diffusion and erosion mechanism. The ' $n$ ' value for formulations F1 and F5 was found to be 0.36 and 1.44 indicate fickian and super case II type of release mechanism where the drug release was controlled only by diffusion in F1 and erosion in F5 formulations. The results of stability studies for optimized formulation F3 revealed no change in physical appearance, hardness and drug indicating the formulation was stable.

\section{REFERENCE}

1. Ambale SM, Ganesh NS, Ramesh B, Deshpande KB. An overview on limitations of gastroretentive drug delivery system. Int $\mathbf{J}$ Pharm Sci Rev Res. 2011;8(2):133-139.

2. Jain AK. Design and Evaluation of Floating Tablets of Vitamin $B_{1}$. Int $J$ Res Pharm Biomed Sci. 2011;2(3):1058-1065.

3. Arunachalam A, Karthikeyan M, Konam K, Prasad PH, Sethuraman S, Ashutoshkumar S, Manidipa S. Floating drug delivery systems: A review. Int J Res Pharm Sci. 2011;2(1):7683.

4. Balagani PK, Pallepati K, Katamreddy JD. Formulation design and evaluation of mucoadhesive buccal tablets of Nitroglycerin. Int J Pharm Pharm Sci. 2014;6(7): 251-259.

5. Balagani PK, Sumalatha YS. Formulation Development and Evaluation of Floating
Tablets of Etodolac. World J Pharm Pharm Sci. 2015;4(7):1516-1532.

6. Chien YW. Novel Drug Delivery Systems. $2^{\text {nd }}$ edition, Revised and expanded. NewYork: Marcel Dekker; 1992.

7. Dash S, Murthy PN, Nath L, Chowdhury P. Kinetic modeling on drug release from controlled drug delivery systems. Acta Pol Pharm. 2010;67(3):217-223.

8. Bhowmik D, Chiranjib B, Chandira M, Jayakar B, Sampath Kumar KP. Floating Drug Delivery System-A Review. Der Pharmacia Lettre. 2009;1(2):199-218.

9. Edukondalu V, Ashok K, Jagadeesh K, Pushpalatha V, Satyanandam S, Lakshmi NV. Formulation and evaluation of oral floating tablets of Atenolol using Okra gum. Der Pharmacia Lettre. 2011;3(3):342-349.

10. Rathod H, Patel V, Modasia M. Floating drug delivery system: innovative approach of gastroretention. Int $\mathrm{J}$ Pharm Sci Rev Res. 2010;4(3):184-192.

11. Irisappan SC, Balagani PK, Narayanan V. Formulation and invitro evaluation of floating drug delivery system for Salbutamol Sulphate. Int $\mathbf{J}$ Pharma Biomed Sc. 2010;1(1):12-15.

12. Ingani HM, Timmermans $\mathrm{J}$, Moes $\mathrm{AJ}$. Conception and in vivo investigation of peroral sustained release floating dosage forms with enhanced gastrointestinal transit. Int $\mathbf{J}$ Pharm. 1987;35(1):157-164.

13. Kawashima Y, Niwa T, Takeuchi H, Hino T, Itoh Y. Hollow microspheres for use as a floating controlled drug delivery system in the stomach. J Pharm Sci. 1992;81(2):135140.

14. Manubolu S, Balagani PK. Formulation Design and Evaluation of Controlled Release Zolmitriptan Rapimelts. J Compr Phar. 2014;1(4):119-135.

15. Mayavanshi AV, Gajjar SS. Floating drug delivery systems to increase gastric retention of drugs: A Review. Res J Pharm Tech 2008;1(4):345-348.

16. Madaka S, Sanka K, Veerareddy PR. Design and evaluation of Hydrochlorothiazide floating drug delivery system. Asian J Pharm Sci 2011;6(5):208-217. 
17. Rahman Z, Ali M, Khar R. Design and evaluation of bilayer floating tablet of captopril. Acta Pharm. 2006;56(1):49-57.

18. Kumar NS. Aceclofenac floating tablets - a promising sustained release dosage form. Int $\mathbf{J}$ Drug Dev \& Res. 2011;3(2):290-300.

19. Irisappan SC, Balagani PK, Jayaveera KN. Characterization of Glibenclamide loaded cellulose acetate microparticles prepared by an emulsion solvent evaporation method. J Pharm Res. 2013;7(8):766-773.

20. Shayeda, Nadigoti J. Floating Drug Delivery Systems. Int J Pharm Sci Nanotech. 2009;2(3):595-604.

21. Sheth PR, Tossounian J. The hydrodynamically balanced systems
$\left(\mathrm{HBS}^{\mathrm{TM}}\right)$ : a novel drug delivery system for oral use. Drug Dev Ind Pharm. 1984;10(2):313-339.

22. Sivabalan M, Vani T, Phaneendhar Reddy V, Anup Jose NG. Formulation and evaluation of gastroretentive glipizide floating tablets. Int $\mathbf{J}$ Compr Pharm. 2011;2(1):1-4.

23. Raju DB, Sreenivas R, Verma MM. Formulation and evaluation of floating drug delivery system of Metformin Hydrochloride. J Chem Pharm Res 2010;2(2):274-278.

24. Zaware SR, Gaikwad PD, Bankar VH, Pawar SP. A Review on Floating Drug Delivery System. Int J Ph Sci. 2010;2(3):834-847.

Cite this article as: Irisappan SC, Paleti N, Balagani PK, Pallepati K. Formulation design and in vitro Evaluation of Floating tablets of an Antiulcer drug using Different Synthetic and Natural polymer. J Compr Phar 2016;3(3):99-114. 